\section{0-036 ASPIRATION TUBING DIAMETER IS ASSOCIATED WITH CONSISTENCY OF INTRALUMINAL ASPIRATION PRESSURE FOR MECHANICAL THROMBECTOMY IN ACUTE ISCHEMIC STROKE: AN EXPERIMENTAL STUDY}

${ }^{1} \mathrm{~L}$ Verhey ${ }^{*},{ }^{2} \mathrm{O}$ Rivera, ${ }^{2} \mathrm{~L}$ Lyons, ${ }^{1} \mathrm{P}$ Mazaris, ${ }^{3} \mathrm{M}$ Khan, ${ }^{1} \mathrm{~J}$ Singer. ${ }^{1}$ Neurological Surgery, Spectrum Health, Michigan State University, Grand Rapids, MI; ${ }^{2}$ Neurological Surgery, Spectrum Health, Grand Rapids, Ml; ${ }^{3}$ Neurology, Spectrum Health, Michigan State University, Grand Rapids, MI

\subsection{6/neurintsurg-2019-SNIS.36}

Introduction/Purpose For patients with acute ischemic stroke due to a large vessel occlusion, aspiration-retrieval methods are increasingly becoming standard-of-care. Several parameters of the standard thrombectomy set-up influence procedure success. We studied, in a controlled experimental setting, the effect of various aspiration tubing on consistency of intraluminal pressure between static and dynamic phases of aspiration, static being aspiration with no flow into the distal access catheter and dynamic being aspiration with active catheter flow.

Materials and methods Standard set-up for all trials included a single distal access catheter $(\mathrm{ID}=0.60$ in) immersed in a canister of water connected by a three-way valve to aspiration tubing with an inline digital manometer at the junction (figure 1). A single vacuum pump was used in all trials. Four types of aspiration tubing, differentiated based on diameter, were studied. Two trials were conducted for each type of aspiration tubing in which the pressure (in $\mathrm{Hg}$ ) was measured in static and dynamic phases. The mean pressure over the two trials was computed for each phase. Percent change was computed between the static and dynamic phases. Data was summarized with descriptive statistics. Student's t-test and Analysis of Variance (ANOVA) with Bonferroni post-hoc analyses were used to compare pressures between the various tubing.

Results The mean percent change between the static and dynamic phases for the four types of aspiration tubing were: Type $158.3 \%$ (22.1 inHg vs. $9.2 \mathrm{inHg}$ ), Type 2 18.5\% (20.3 vs. 16.5), Type $331.6 \%$ (25.3 vs 17.3), and Type $42.7 \%$ (25.3 vs. 24.6) (table 1). Change in pressure between static and dynamic phases was significantly different for tubing Types 1-3 $(\mathrm{p}<0.05)$. Intraluminal pressure was constant between static and dynamic phases for Type 4 (p 0.152, 95\% CI -0.7-2.2).

Conclusion Intraluminal pressure for the aspiration tubing with the largest diameter (Type 4) was constant over static and

\begin{tabular}{clllll}
\multicolumn{2}{l}{ Abstract 0-036 Table 1 } & & \\
\hline Tubing & $\begin{array}{l}\text { Internal } \\
\text { diameter (in) }\end{array}$ & & $\begin{array}{l}\text { Static pressure } \\
\text { (inHg) }\end{array}$ & $\begin{array}{l}\text { Dynamic pressure } \\
\text { (inHg) }\end{array}$ & $\begin{array}{l}\text { \% } \\
\text { Change }\end{array}$ \\
\hline Type 1 & 0.088 & Trial 1 & 24.76 & 9.2 & 62.8 \\
& & Trial 2 & 19.53 & 9.27 & 52.53 \\
& & Mean & 22.145 & 9.235 & 58.3 \\
Type 2 & \multirow{2}{*}{0.11} & Trial 1 & 20.35 & 16.45 & 19.16 \\
& & Trial 2 & 20.15 & 16.54 & 17.92 \\
& & Mean & 20.25 & 16.495 & 18.54 \\
Type 3 & \multirow{2}{*}{0.11} & Trial 1 & 25.05 & 16.85 & 32.73 \\
& & Trial 2 & 25.56 & 17.77 & 30.48 \\
& & Mean & 25.305 & 17.31 & 31.59 \\
Type 4 & \multirow{2}{*}{0.218} & Trial 1 & 25.69 & 24.48 & 4.71 \\
& & Trial 2 & 25.02 & 24.66 & 1.44 \\
& & Mean & 25.255 & 24.57 & 2.71 \\
\hline
\end{tabular}

dynamic aspiration. We suggest that larger diameter aspiration tubing provides less resistance to flow and therefore may permit more reliable distal catheter - thrombus face engagement, which may translate into improved reperfusion outcomes. Future studies will evaluate the relationship between aspiration tubing type and thrombectomy outcome.

Disclosures L. Verhey: None. O. Rivera: None. L. Lyons: None. P. Mazaris: None. M. Khan: None. J. Singer: 2; C; Stryker, Medtronic.

\section{Oral poster abstracts}

\section{P-001 CAROTID ARTERY STENTING USING OVERLAPPED DOUBLE CLOSED-CELL STENTS FOR UNSTABLE PLAQUE}

${ }^{1} \mathrm{~K}$ Takayama*, ${ }^{1} \mathrm{~K}$ Myouchin, ${ }^{2} \mathrm{~T}$ Wada, ${ }^{3} \mathrm{~S}$ Kurokawa, ${ }^{2} \mathrm{~K}$ Kichikawa. ${ }^{1}$ Radiology and Interventional Neuroradiology, Ishinnkai Yao General Hospital, Yao city, Japan; ${ }^{2}$ Radiology, Nara Medical University, Kashihara, Japan; ${ }^{3}$ Neurosurgery, Ishinnkai Yao General Hospital, Yao City, Japan

\subsection{6/neurintsurg-2019-SNIS.37}

Purpose Stent design is one of the risk factors associated with periprocedural ischemic complications during carotid artery stenting (CAS). Closed-cell stents have a lower rate of ischemic complications than open-cell stents, and it has been reported

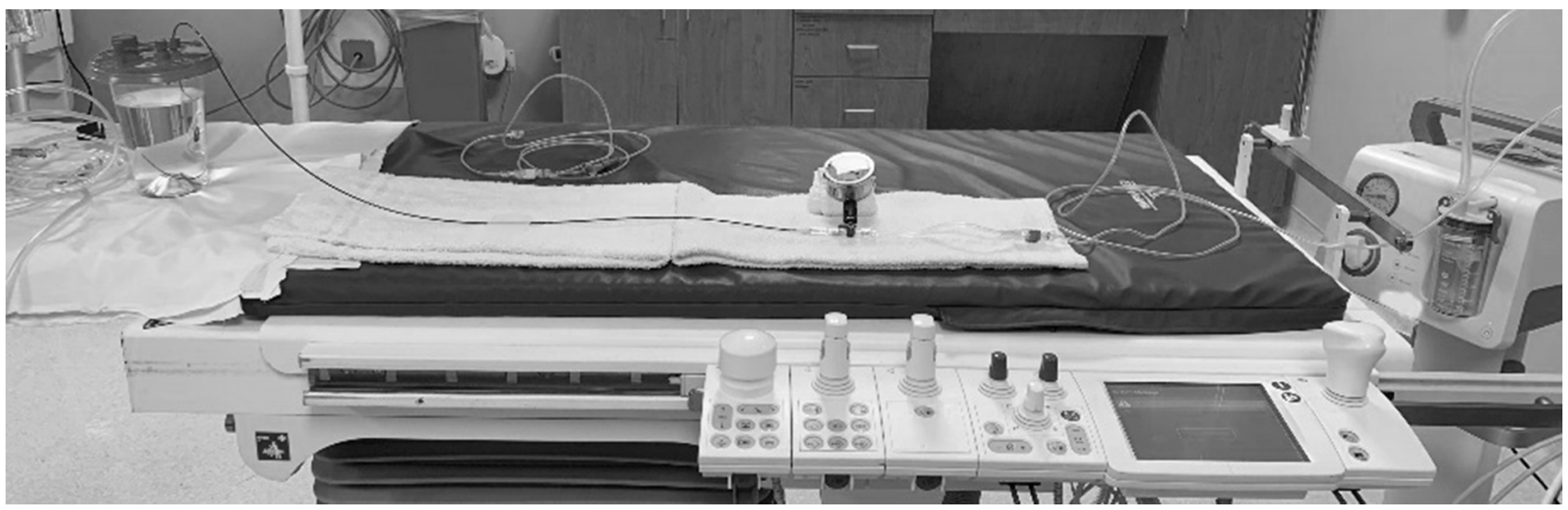

